\title{
Measurement and Prediction of Sediment Yields in Wisconsin Streams
}

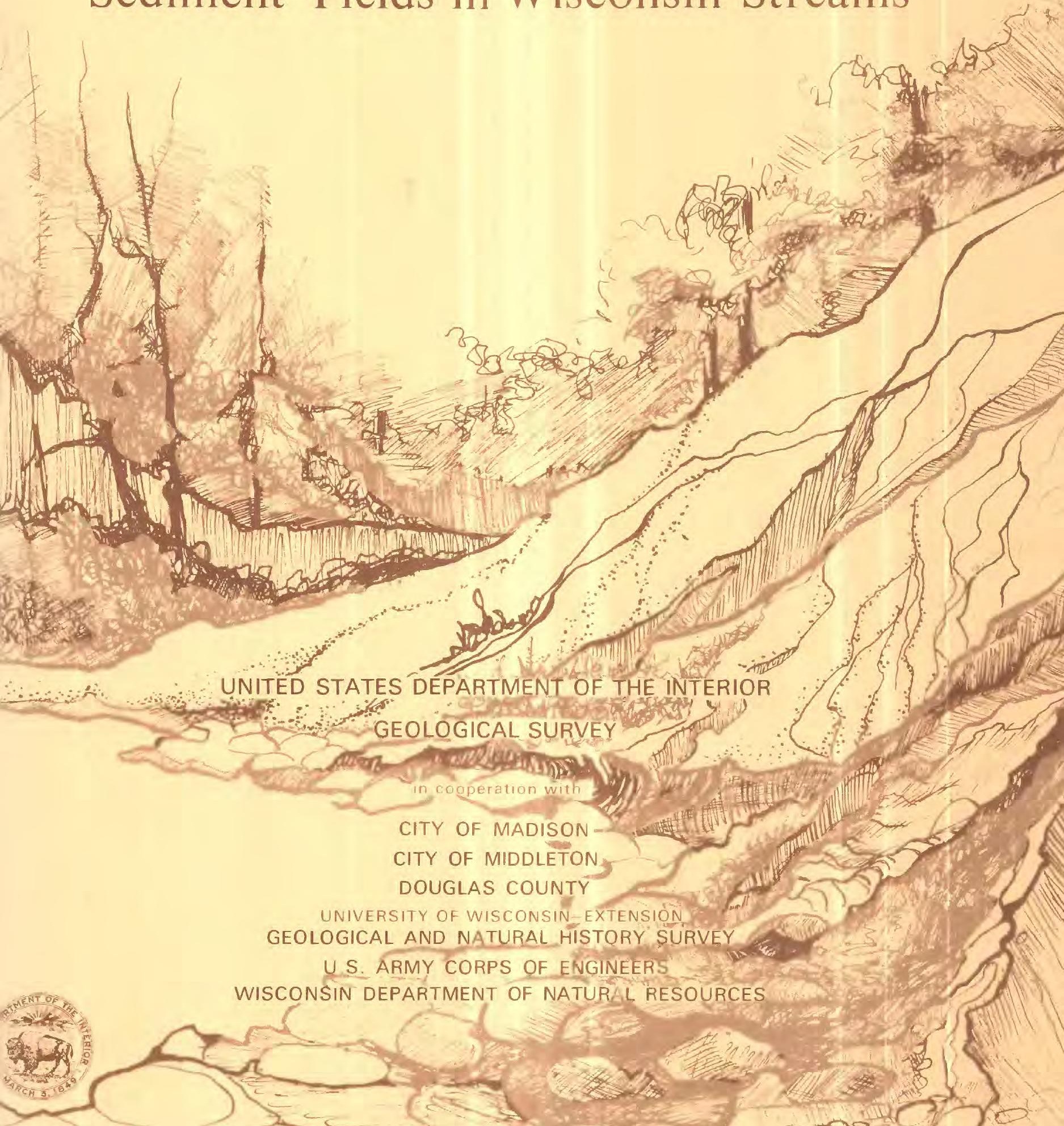




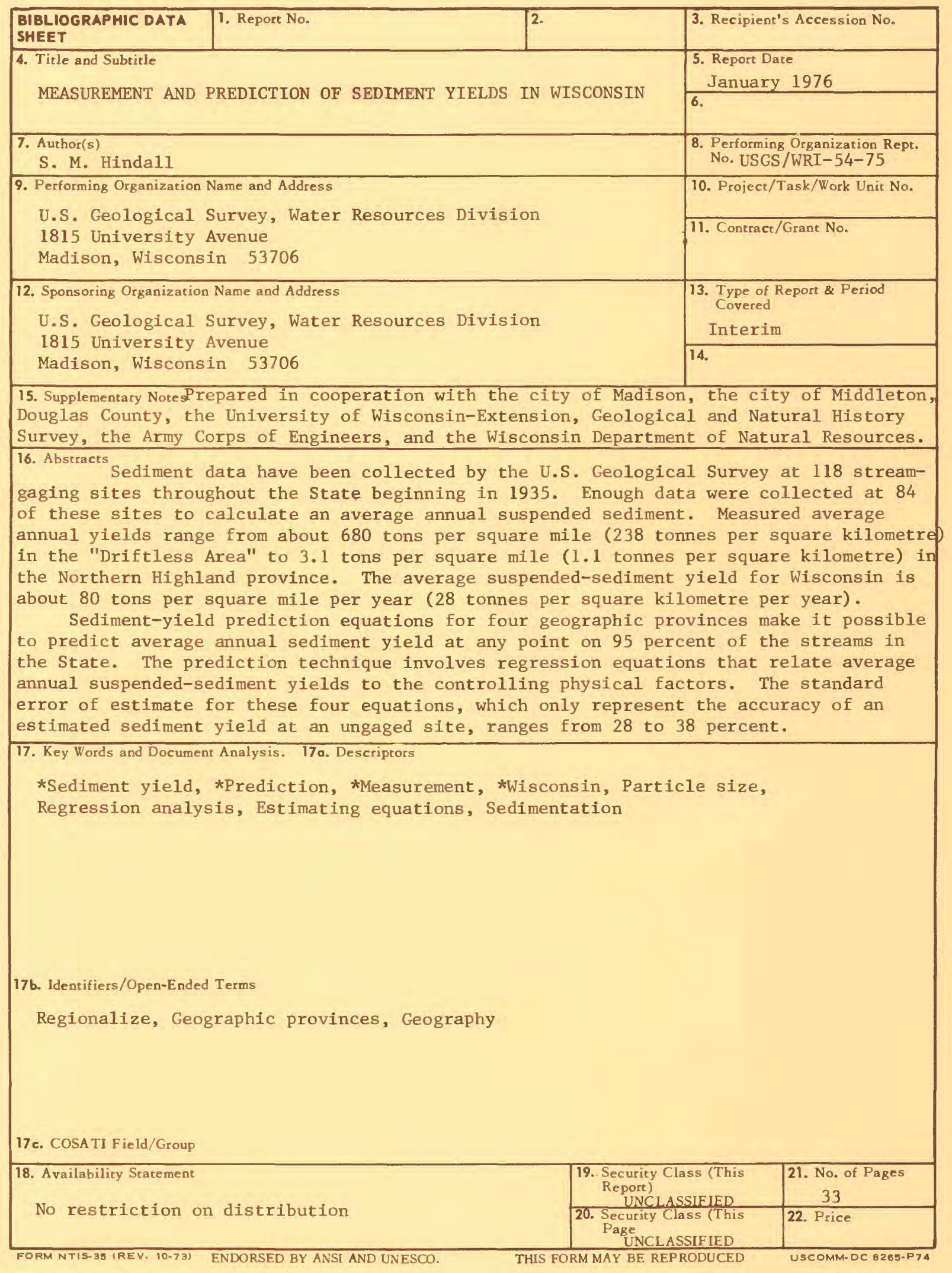




\section{Measurement and Prediction of Sediment Yields in Wisconsin Streams}

S. M. Hindall

\section{U.S. GEOLOGICAL SURVEY}

Water-Resources Investigations 54-75

Prepared in cooperation with the

City of Madison,

City of Middleton,

Douglas County,

University of Wisconsin-Extension,

Geological and Natural History Survey,

U.S. Army Corps of Engineers,

Wisconsin Department of Natural Resources 


\title{
UNITED STATES DEPARTMENT OF THE INTERIOR \\ Thomas S. Kleppe Secretary
}

\author{
GEOLOGICAL SURVEY \\ V.E. McKelvey Director
}

For additional information write to:

U.S. Geological Survey

1815 University Avenue

Madison, Wisconsin 53706 


\section{Contents}

Abstract-_- 1

Introduction-_-

Sediment data and yields of Wisconsin streams-_-_-

Predicting sediment yields in Wisconsin streams-

Glossary--

Selected references-

\section{Illustrations}

Figure 1-6. Maps of Wisconsin showing:

1. Sediment-data network- 3

2. Regionalized suspended-sediment yields--_-_-_-_-- 9

3. Geographic provinces and "Driftless Area"- 13

4. Average annual runoff-- 22

5. Precipitation-intensity index- 24

6. Mean frost depth on February 28- 25

\section{Tables}

Table 1. Sediment yield, concentration, and particle-size data-------- 4

2. Sediment-data site network-_ 10

3. Equations for prediction of suspended-sediment yield--- 16

4. Observed versus computed average annual long-term, suspended-sediment yields-_- 


\section{Conversion Factors}

For the use of those readers who may prefer to use metric units rather than English units, the conversion factors for terms used in this report are listed below.

Multiply English unit

in (inches)

ft (feet)

mi (miles)

$\mathrm{mi}^{2}$ (square miles)

$\mathrm{ft} / \mathrm{mi}$ (feet per mile)

gal/min (gallons per minute)

tons/mi 2 (tons per square mile)

$\mathrm{ft} 3 / \mathrm{s}$ (cubic feet per second)

(ft $3 / \mathrm{s}$ ) $/ \mathrm{mi}^{2}$ (cubic feet

per second per square mile)
By

$$
25.40
$$

.3048

1.609

2.590

.1894

$6.309 \times 10^{-2}$

.3503

$2.832 \times 10^{-2}$

$1.093 \times 10^{-2}$
To obtain metric unit

mm (millimetres)

$\mathrm{m}$ (metres)

$\mathrm{km}$ (kilometres)

$\mathrm{km}^{2}$ (square kilometres)

$\mathrm{m} / \mathrm{km}$ (metres per kilometre)

1/s (litres per second)

tonnes $/ \mathrm{km}^{2}$ (tonnes per square kilometre)

$\mathrm{m}^{3} / \mathrm{s}$ (cubic metres per second)

$\left(\mathrm{m}^{3} / \mathrm{s}\right.$ ) $/ \mathrm{km}^{2}$ (cubic metres per second per square kilometre) 


\title{
Measurement and Prediction of Sediment Yields in Wisconsin Streams
}

\author{
S. M. Hindall
}

\section{Abstract}

Sediment data of some form have been collected by the U.S. Geological Survey at 118 stream-gaging sites throughout Wisconsin, beginning in 1935 . The average concentration of suspended sediment for Wisconsin streams is low in comparison with that of many streams in the United States- 110 milligrams per litre for Wisconsin, as compared with 600 milligrams per litre for 50 percent of the United States (Rainwater, 1962). Enough data have been collected at 84 of the 118 sites to calculate an average annual suspended-sediment yield at those sites.

Measured average annual yields range from about 680 tons per square mile (238 tonnes per square kilometre) in the "Driftless Area" to 3.1 tons per square mile ( 1.1 tonnes per square kilometre) in the Northern Highland province. The average suspended-sediment yield for Wisconsin is about 80 tons per square mile per year (28 tonnes per square kilometre per year). Only three areas in the State may be considered to have a sediment problem. They are sections of the "Driftless Area" of southwestern Wisconsin, the Lake Superior red-clay area, and areas of expanding urbanization in southeastern Wisconsin.

Sediment-yield prediction equations have been developed for the Northern Highland province, the Central Plain province, the Eastern Ridges and Lowlands province, and the "Driftless Area" (Martin, 1932 and Thwaites, 1956). These four equations make it possible to predict average annual suspendedsediment yields at any point on about 95 percent of the streams in the State. The prediction technique involves regression equations that relate average annual suspended-sediment yields to factors, such as topography, soils, land use and cover, stream hydraulics, and climatic conditions. The standard error of estimate for these equations, which only represents the accuracy of an estimated sediment yield at an ungaged site, ranges from 28 to 38 percent. 
INIHODUCITOW

The Ui.S. Geologicall Survey has beem collecting flluviall sediment data at variows poimts thiroughout Wiscomsin for about 20 years. Host of these data frave beem published in the "Mater Resources Data for Miscomsim anumall repports.

This repont presemts practical amd wsefwl sedimemt-yield infomation for Wisconsin. Heasured ad estimated sediment yielids are supplemented by information on suspended-sediment concemtration and particle size of suspemded amd bed moterial for 84 sites in the State. To expand the usfefulimess of these data, an adifitiomal section fin the report presemts a method to estimate or predict sediment yields im maged streams.

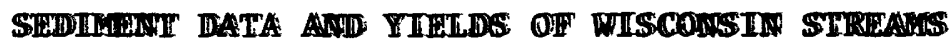

Various amounts and types of sedimemt datra have been collected by the U.S. Geologieal Senvey in: cooperation with the city of Haulfsom, the city of

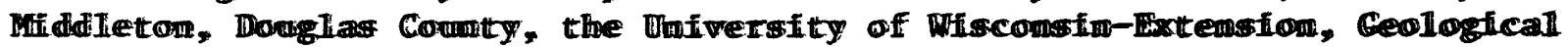
and Nattural History Survey, the U.S. Army Corps of Hugineers, and the Misconsin Departmemt of Hattural Resowres at 118 stream-gaging sites throwginowt the State begimming im I935. Figure I sthows the sites that are befing momitored along with aIl active and fmactive sites that have emowg sediment data to calculate an average ampal sedimedt yielid.

Three types of sedimemit data are awailiblie for the state. The most comman type of dat are suspended-sediment concentration. These ditta, when used with stream discharge, make it possible to determume the amowt of suspended sediment transported by the stream. Particle sfize of both suspended and bed materiall helps describe the physical characteristics of the transported sediments. Both types of data, if collected comcurremtly, cam be wsed with hydramilic data at the collection site to estimate total sediment transport. There are limited data on chemical characteristics of the transported sedimeuts.

Sedimemt yields were calculated for all sites where senfficiemt concentration data have been collected to deffine sediment difscharges over the complete ramge of water discharge. The reliation between sedimemt amd water discharge is used with streamflow-duration curves to callewiate the average ammual suspemded-sediment yield.

Sediment-yieId, suspended-sediment concentration, and some particliesize data for 84 strean-gaging stations ill the State were complied in table 1. The short-term average anmwal swspended-sediment vields were computed for the period of sediment record throwgit the 1973 wer year. The long-term, suspended-sediment yieldis were determined by adjustimg: the short-term yields to a 10-year base period, 1961-70. The average anmual sediment yields include an estimate of bed-material discharge. 


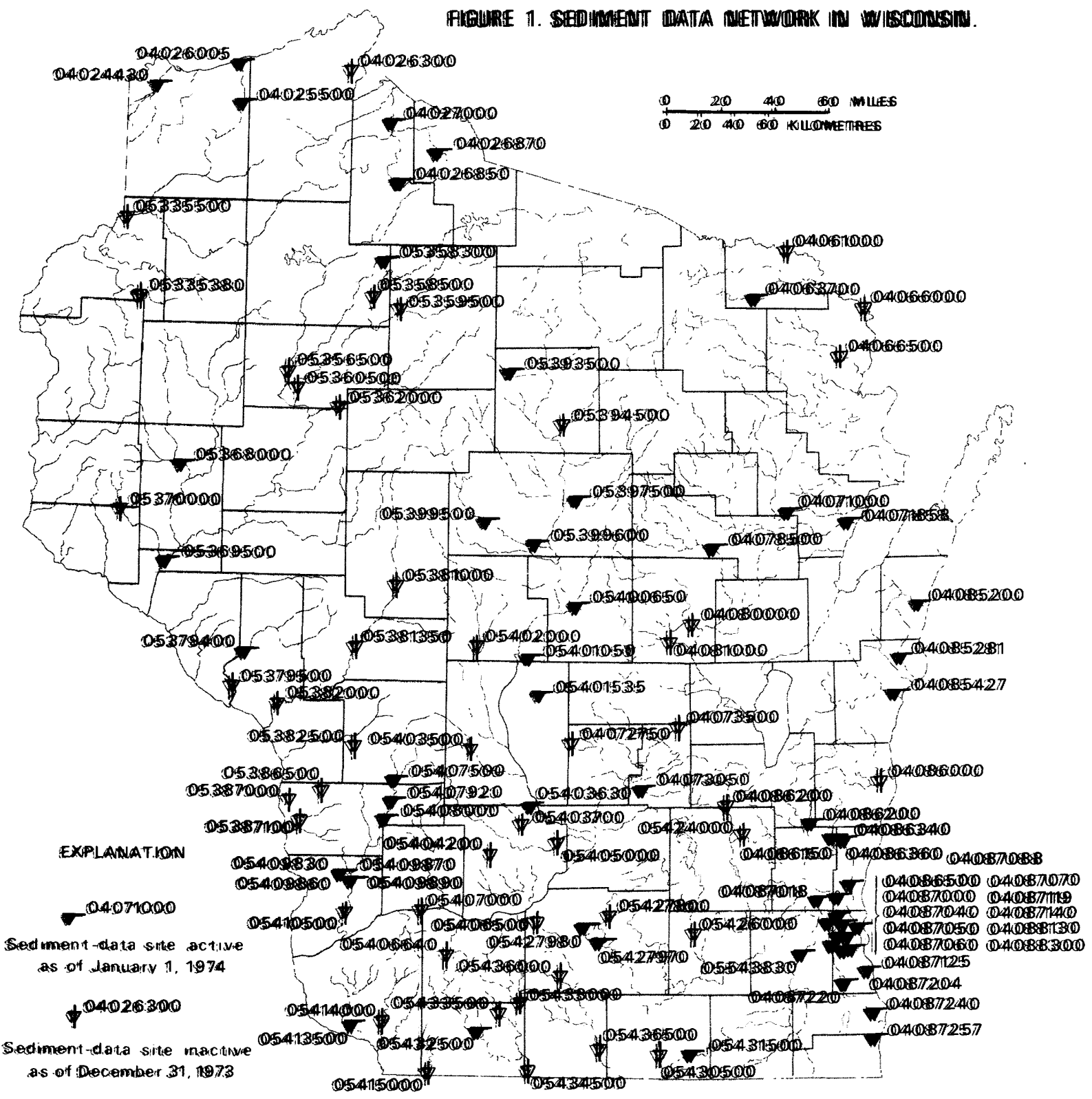




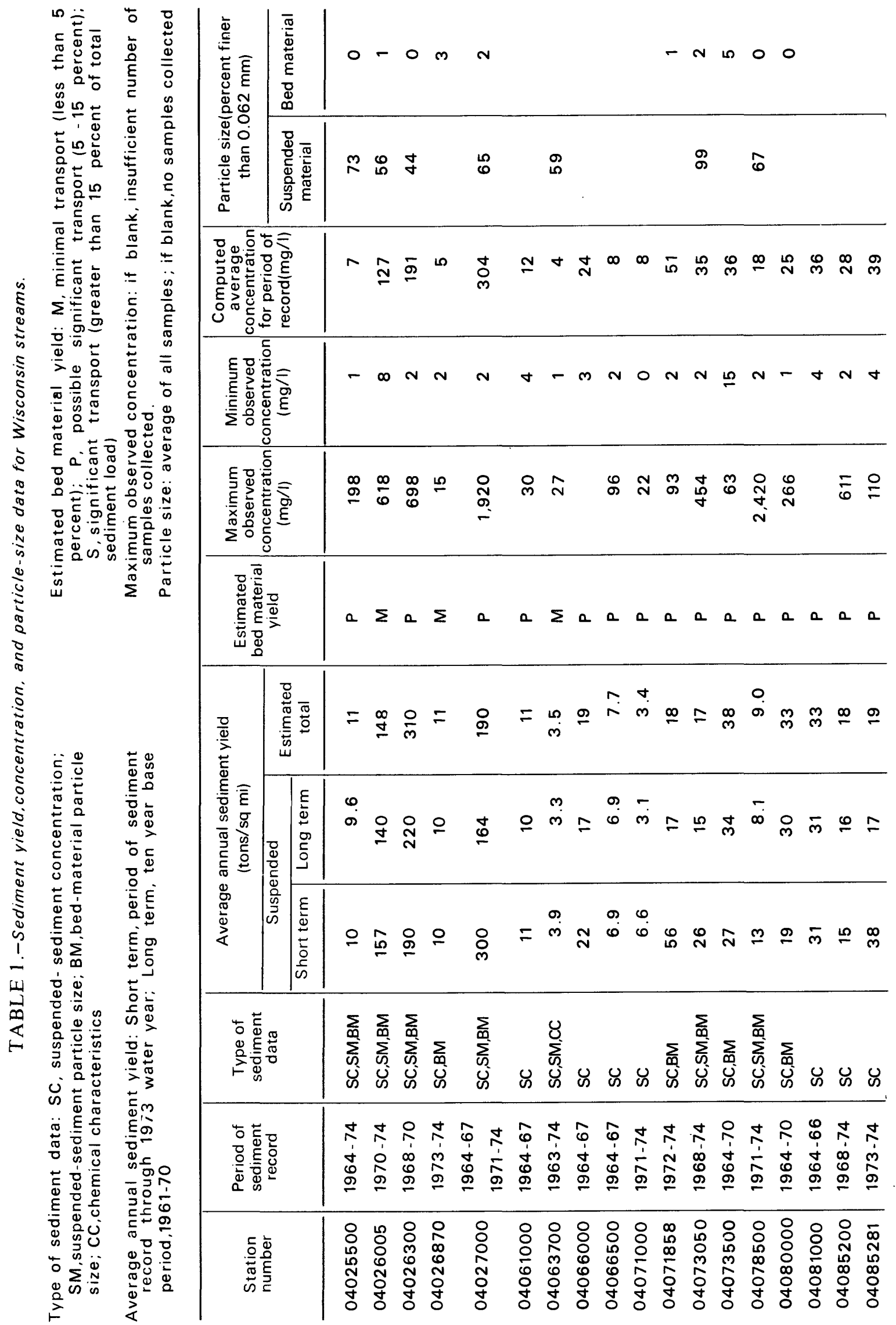


๗

N

$\stackrel{\llcorner}{\sim}$

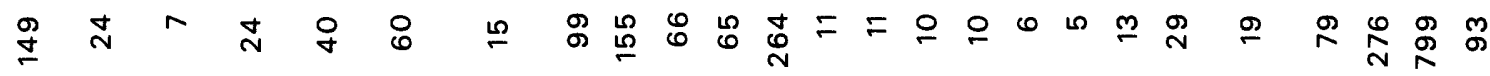

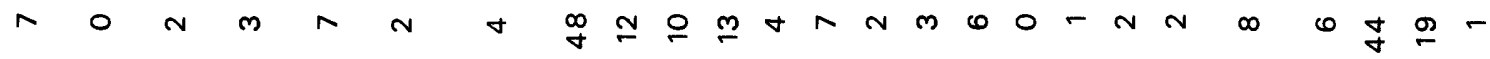

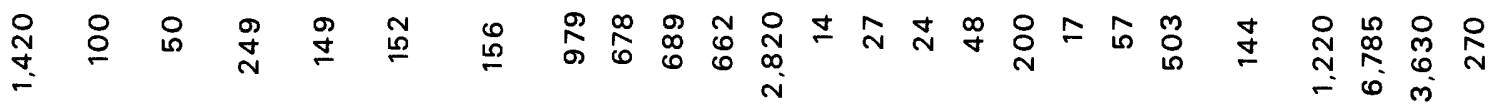

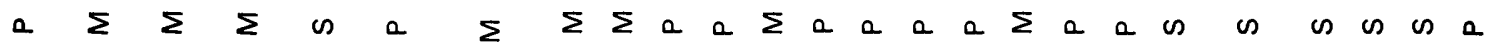

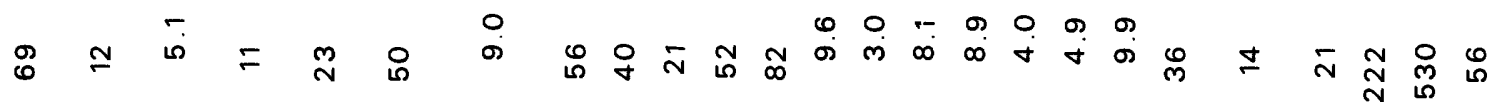

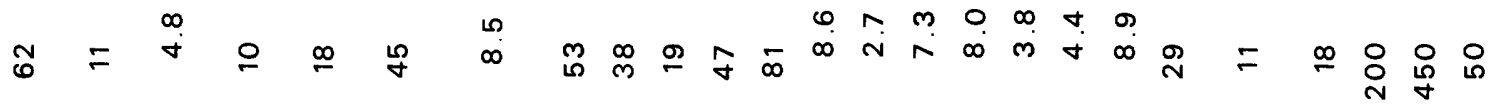

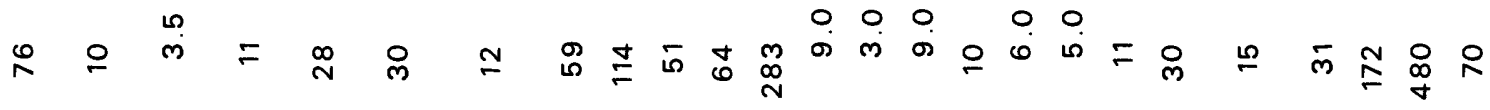

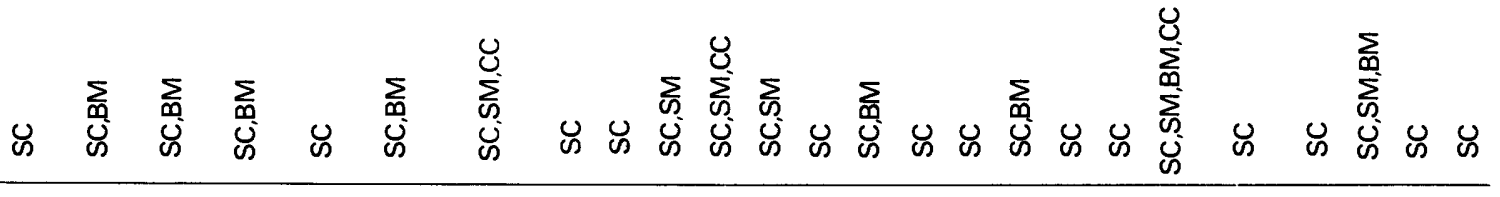

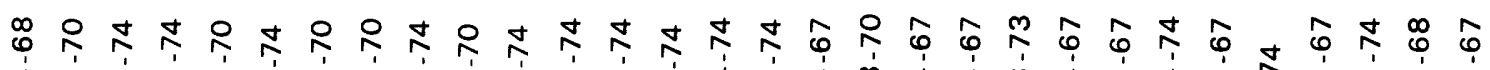
守

\begin{tabular}{|c|c|c|c|c|c|c|c|c|c|c|c|c|c|c|c|c|c|c|c|}
\hline $\begin{array}{l}\infty \\
\infty \\
0\end{array}$ & 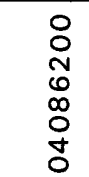 & 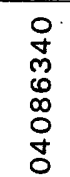 & $\begin{array}{l}0 \\
\text { m } \\
0 \\
\infty \\
0\end{array}$ & $\begin{array}{l}5 \\
0 \\
0 \\
0\end{array}$ & & & \begin{tabular}{l}
\multirow{O}{N}{} \\
$\underset{N}{\infty}$ \\
0 \\
$\vdots$ \\
0
\end{tabular} & 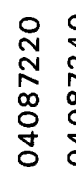 & 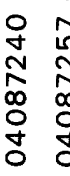 & 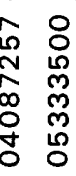 & $\begin{array}{l}0 \\
\infty \\
m \\
0 \\
\tilde{M} \\
m \\
0 \\
0 \\
0\end{array}$ & $\begin{array}{ll}0 & 0 \\
0 & 0 \\
0 & 5 \\
0 & 0 \\
0 & 0 \\
0 & 0 \\
0 & 0 \\
0 & 0\end{array}$ & 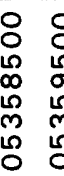 & $\begin{array}{l}8 \\
8 \\
0 \\
0 \\
0 \\
0\end{array}$ & & & & & 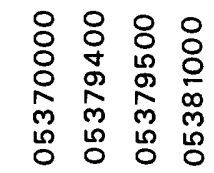 \\
\hline
\end{tabular}




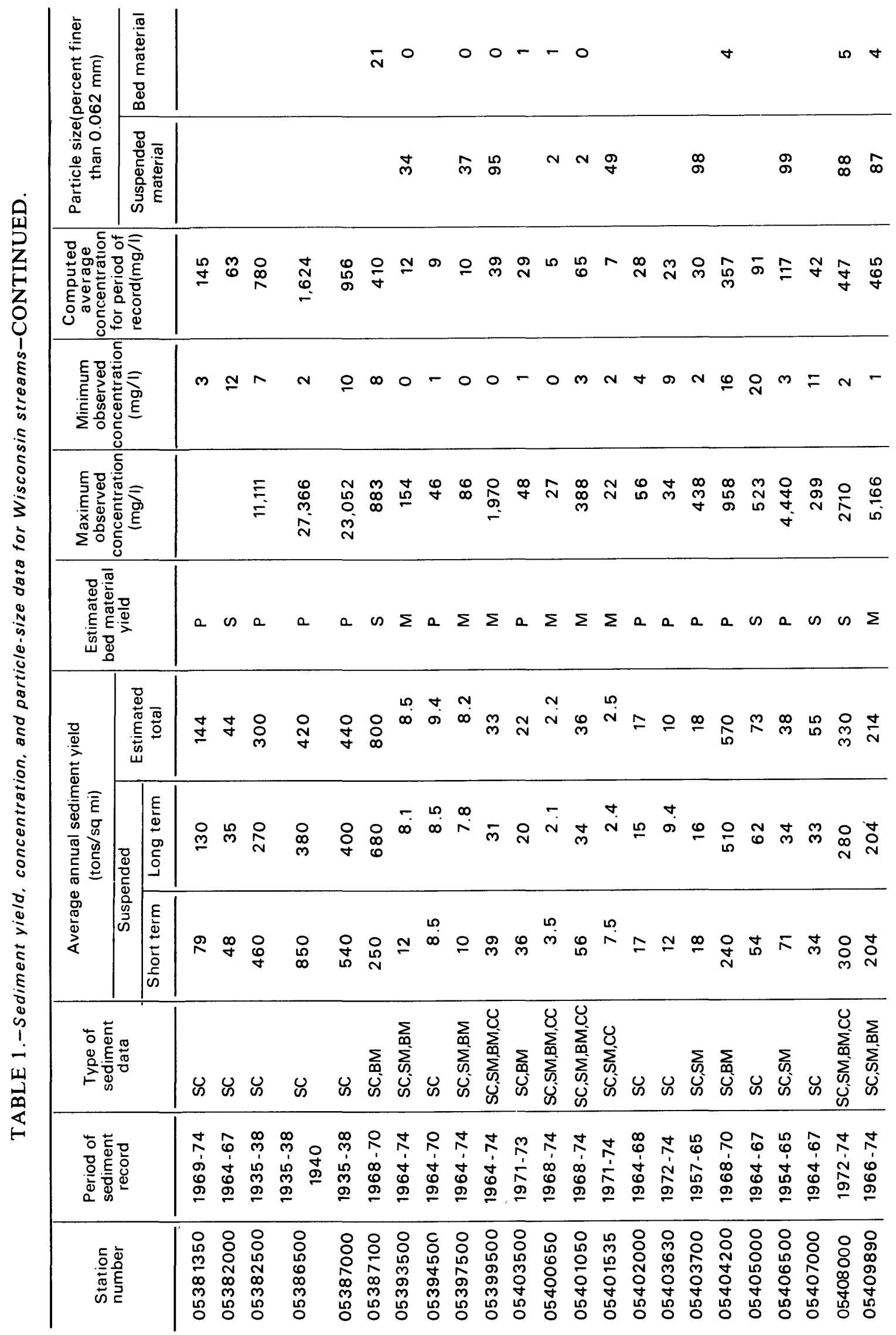




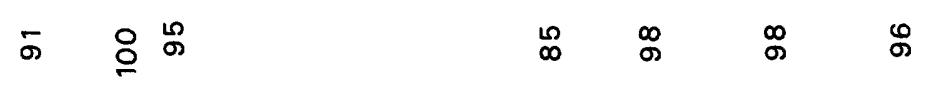

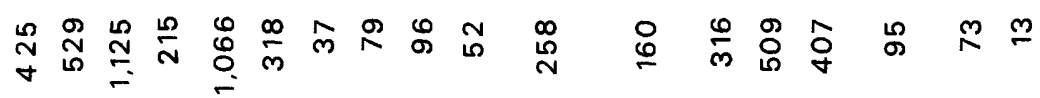

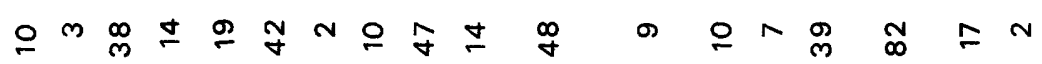

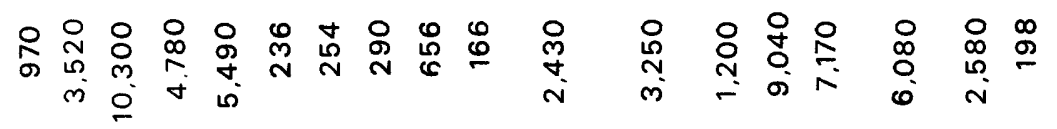

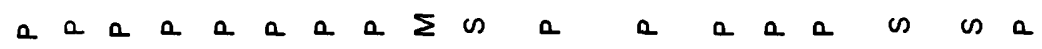

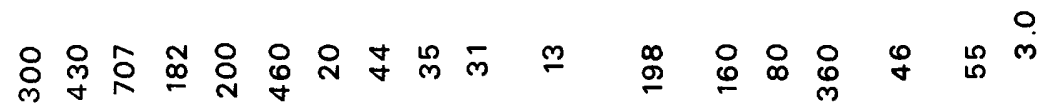

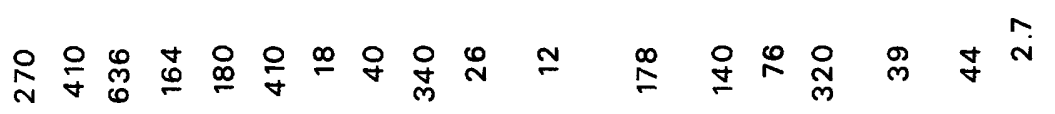

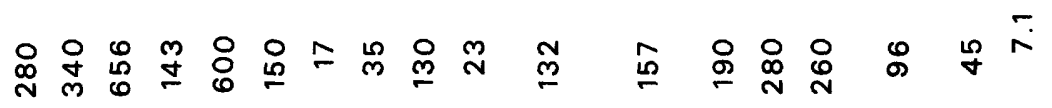

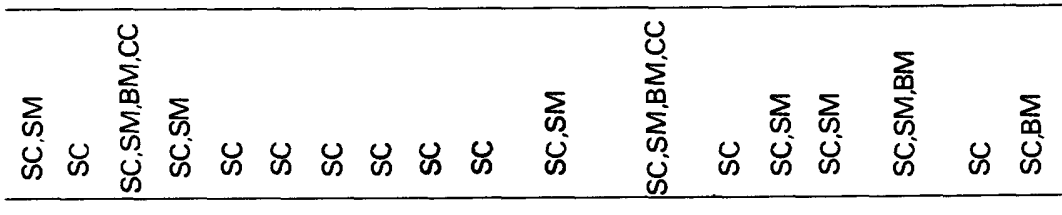

군

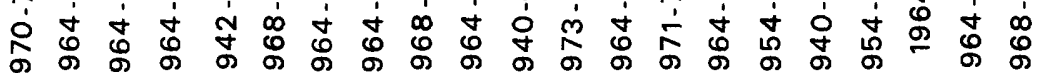

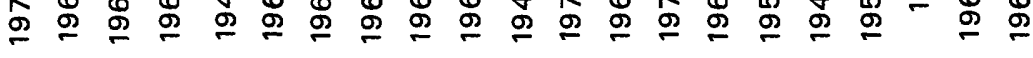

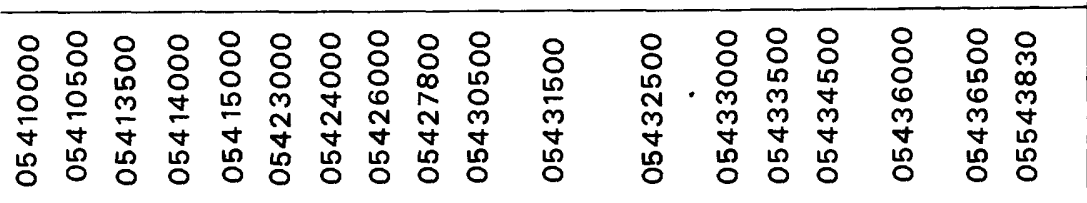


Particle-size data presented in table 1 give the percentage of suspended and bed material that is finer than $0.062 \mathrm{~mm}$ (millimetre), the division between silt and sand sizes.

The regionalized suspended-sediment yield (fig. 2) was based on measured yields adjusted to the 10-year (long-term) base period plotted at the centroid of the drainage basin. This regionalized map is only a general estimate of sediment yields and should be treated as such.

Sediment yields for some basins do not fit into any regional pattern. This is partly due to local actions, partly to an inherent variability in sediment transport, and partly to a lack of detailed sediment data.

As of October 1, 1974, there were 60 sites in the State where sediment data were being collected at intervals ranging from daily to intermittent (table 2). Ten stations were sampled daily and nine were sampled weekly. The remaining 41 were sampled at frequencies varying from individual storms to approximately monthly. During high-water periods the sampling frequency for all stations was increased to at least daily where possible. Twenty-four of these stations were operated for special sedimentationrelated projects. Particle-size data of both suspended and bed material were being collected at every site on an "event" basis.

Recently a small program to determine chemical as well as physical characteristics of the transported sediments was begun in the State. The amounts of certain chemical constituents that are sorbed on the sediments and transported "piggy-back" by the sediments greatly exceed, in some instances, the amounts dissolved in the water. This property of some types of sediments to sorb large amounts of chemical makes sediment a tremendous potential carrier for possible contaminates.

Wisconsin is fortunate to have no serious overall sediment problem as is indicated by generally low measured yields. Local or point-source problems may cause high yields in some areas, but their effect on regional sediment yields is minimal. The average annual suspended-sediment yield for Wisconsin is only 80 tons $/ \mathrm{mi}^{2}$ (28 tonnes $/ \mathrm{km}^{2}$ ). The average dischargeweighted concentration of suspended sediment for Wisconsin streams is about $110 \mathrm{mg} / 1$ (milligrams per litre). This is very low when compared to that of streams throughout the United States. Ninety percent of the streams in the United States have a discharge-weighted suspended-sediment concentration of less than $8,000 \mathrm{mg} / 1$, and only 50 percent of the streams have a suspended-sediment concentration of less than $600 \mathrm{mg} / 1$ (Rainwater, 1962). The $110 \mathrm{mg} / 1$ definitely puts Wisconsin streams in the lower percentage of the United States streams.

The highest yields in the State are in the "Driftless Area" (fig. 3). Measured average annual suspended-sediment yields range from 34 to 680 tons $/ \mathrm{mi}^{2}$ (12 to 238 tonnes $/ \mathrm{km}^{2}$ ) for this area with the median yield being 200 tons $/ \mathrm{mi}^{2}$ (70 tonnes $/ \mathrm{km}^{2}$ ). Here the silty soils on very steep slopes promote high sediment yields. 


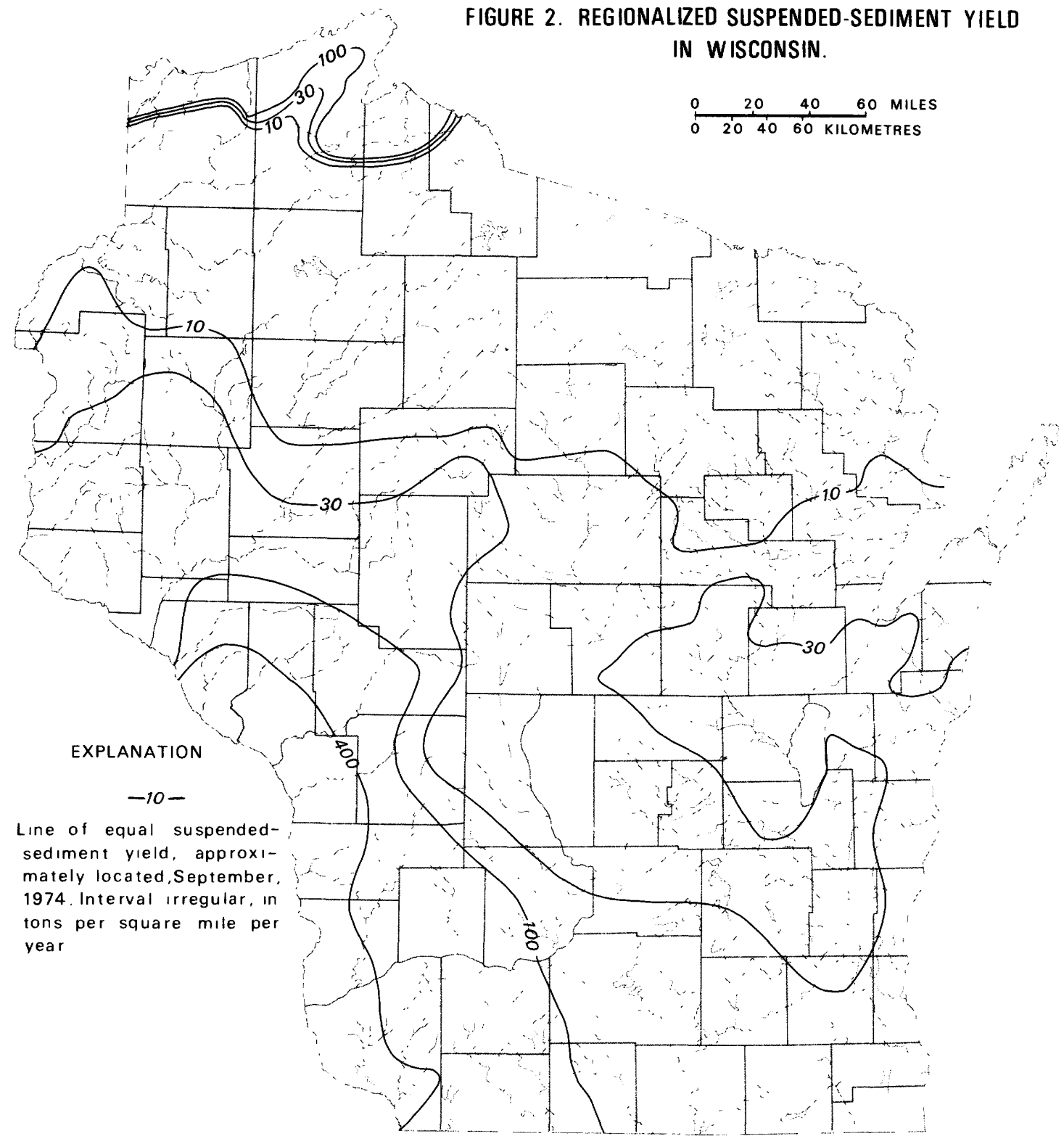


Table 2.--Sediment-data site network for Wisconsin

Site number

04024430

04025500

04026005

04026300

04026450

04026870

04027000

04061000

04063700

04066000

04066500

04071000

04071858

04073050

04073500

04078500

04080000

04081000

04085200

04085281

04086000

04086150

04086200

04086340

04086360

04086500

04087000

04087018

04087030

04087040

04087050

04087060

04087070

04087088

04087119

04087120

04087125

04087130

04087140

04087204

04087220

04087240

04087257

05333500

05335380
Site name

Nemadji River near Superior

Bois Brule River at Brule

Bois Brule River near Lake Superior

Soix River near Washburn

Bad River near Mellen

Alder Creek near Upson

Bad River near Odanah

Brule River near Florence

Popple River near Fence

Menominee River near Pembine

Pike River at Amberg

Oconto River near Gillett

Pensaukee River near Pensaukee

Grand River near Kingston

Fox River at Berlin

Embarrass River near Embarrass

Little Wolf River at Royalton

Waupaca River at Waupaca

Kewaunee River at Kewaunee

East Branch Twin River at Mishicot

Sheboygan River at Sheboygan

Milwaukee River at Kewaskum

East Branch Milwaukee River near New Fane

North Branch Milwaukee River near Fillmore

Milwaukee River at Waubeka

Cedar Creek near Cedarburg

Milwaukee River at Milwaukee

Menomonee River at Germantown

Menomonee River at Menomonee Falls

Menomonee River at Butler

Little Menomonee River near Friestadt

Noyes Creek at Milwaukee

Little Menomonee River at Milwaukee

Underwood Creek at Wauwatosa

Honey Creek at Wauwatosa

Menomonee River at Wauwatosa

Schoonmaker Creek at Wauwatosa

Hawley Road Storm Sewer at Wauwatosa

Menomonee River at Milwaukee

Oak Creek near South Milwaukee

Root River near Franklin

Root River at Racine

Pike River near Racine

St. Croix River near Danbury

Bashaw Brook near Shell Lake
Site status

Active

Active

Active

Discontinued

Active

Active

Active

Discontinued

Active

Discontinued

Discontinued

Active

Active

Active

Discontinued

Active

Discontinued

Discontinued

Active

Active

Discontinued

Active

Active

Active

Discontinued

Active

Active

Active

Active

Active

Active

Active

Active

Active

Active

Active

Active

Active

Active

Active

Active

Active

Active

Discontinued

Discontinued 
Table 2.--Sediment-data site network for Wisconsin--Continued

Site number

05356500

05358300

05358500

05359500

05360500

05362000

05368000

05369500

05370000

05379400

05379500

05381000

05381350

05382000

05382500

05386500

05387000

05387100

05393500

05394500

05397500

05399500

05399600

05400650

05401050

05401535

05402000

05403500

05403630

05403700

05404200

05405000

05406500

05407000

05407500

05407920

05408000

05409830

05409860

05409870

05409890

05410000

05410500

05413500

05414000
Site name

Chippewa River near Bruce

Pine Creek near Oxbo

Flambeau River at Babbs Island near Winter

South Fork Flambeau River near Phillips

Flambeau River near Bruce

Jump River at Sheldon

Hay River at Wheeler

Chippewa River at Durand

Eau Galle River at Spring Valley

Trempealeau River at Arcadia

Trempealeau River at Dodge

Black River at Neillsville

Levis Creek near Black River Falls

Black River near Galesville

Little La Crosse River near Leon

Coon Creek at Coon Valley

Coon Creek at Stoddard

North Fork Bad Axe River near Genoa

Spirit River at Spirit Falls

Prairie River near Merrill

Eau Claire River at Kelley

Big Eau Pleine River near Stratford

Big Eau Pleine River near Mosinee

Little Plover River at Plover

Tenmile Creek near Nekoosa

Big Roche a Cri Creek near Adams

Yellow River at Babcock

Lemonweir River at New Lisbon

Hulburt Creek near Wisconsin Dells

De11 Creek near Lake Delton

Lawrence Creek near Westfield

Baraboo River near Baraboo

Black Earth Creek at Black Earth

Wisconsin River at Muscoda

Kickapoo River at Ontario

Kickapoo River near Rockton

Kickapoo River at La Farge

North Fork Neder1o Creek near Gays Mills

South Fork Nederlo Creek near Gays Mills

Nederlo Creek near Gays Mills

Nederlo Creek near Gays Mills

Kickapoo River at Gays Mills

Kickapoo River at Steuben

Grant River at Burton

Platte River near Rockville
Site status

Discontinued

Active

Discontinued

Discontinued

Discont inued

Discontinued

Active

Active

Discontinued

Active

Discontinued

Discontinued

Discontinued

Discontinued

Discontinued

Discontinued

Discontinued

Discontinued

Active

Discontinued

Active

Active

Active

Active

Active

Active

Discontinued

Discontinued

Active

Discontinued

Discontinued

Discontinued

Discontinued

Discontinued

Active

Active

Active

Active

Active

Active

Active

Active

Discontinued

Active

Discontinued 
Table 2.--Sediment-data site network for Wisconsin--Continued

Site number

05415000

05423000

05424000

05426000

05427800

05427948

05427970

05430500

05431500

05432500

05433000

05433500

05434500

05436000

05436500

05543830
Site name

Galena River at Buncombe

West Branch Rock River near Waupun

East Branch Rock River near Mayville

Crawfish River at Milford

Token Creek near Madison

Pheasant Branch at Middleton

Willow Creek at Madison

Rock River at Afton

Turtle Creek near Clinton

Pecatonica River at Darlington

East Branch Pecatonica River near Blanchardville

Yellowstone River near Blanchardville

Pecatonica River at Martintown

Mount Vernon Creek near Mount Vernon

Sugar River near Brodhead

Fox River at Waukesha
Site status

Discontinued

Discontinued

Discontinued

Discontinued

Discontinued

Active

Active

Discontinued

Active

Active

Discontinued

Discontinued

Discontinued

Discontinued

Discontinued Active

The lowest average annual suspended-sediment yields are in the Northern Highland province of the State (fig. 3). Large areas of heavy forests, very little crop farming, and gentle topography all combine to keep yields low. Measured average annual suspended-sediment yields range from 3.1 to 31 tons $/ \mathrm{mi}^{2}$ ( 1.1 to 11 tonnes $\left./ \mathrm{km}^{2}\right)$ in this area with the median yield being 8.3 tons $/ \mathrm{mi}^{2}\left(2.9\right.$ tonnes $\left./ \mathrm{km}^{2}\right)$.

Measured average annual suspended-sediment yields in the Eastern Ridges and Lowlands province (fig. 3) range from 2.7 to 410 tons $/ \mathrm{mi}^{2}(0.9$ to 144 tonnes $\left./ \mathrm{km}^{2}\right)$. The median yield in this area is 18 tons $/ \mathrm{mi}^{2}\left(6.3\right.$ tonnes $\left./ \mathrm{km}^{2}\right)$. This large range of yields is normal for some agricultural areas and for agricultural areas that are being converted to urban areas. Most of the extremely high yields are due to point-source erosion problems that are local and generally of short duration. For example, when an area or subdivision is developed, sediment yields increase drastically during the construction period, but generally return to near preconstruction levels after construction is completed. Point-source erosion problems are the easiest to correct and have the most immediate effect on sediment yields and therefore should receive the greatest attention.

Similar midrange average annual suspended-sediment yields are found in the Central Plain province (fig. 3). The measured yields range from 2.1 to 50 tons $/ \mathrm{mi}^{2}\left(0.7\right.$ to 17 tonnes $\left./ \mathrm{km}^{2}\right)$ with a median yield in this area of 17 tons $/ \mathrm{mi}^{2}$ ( 5.9 tonnes $\left./ \mathrm{km}^{2}\right)$. 


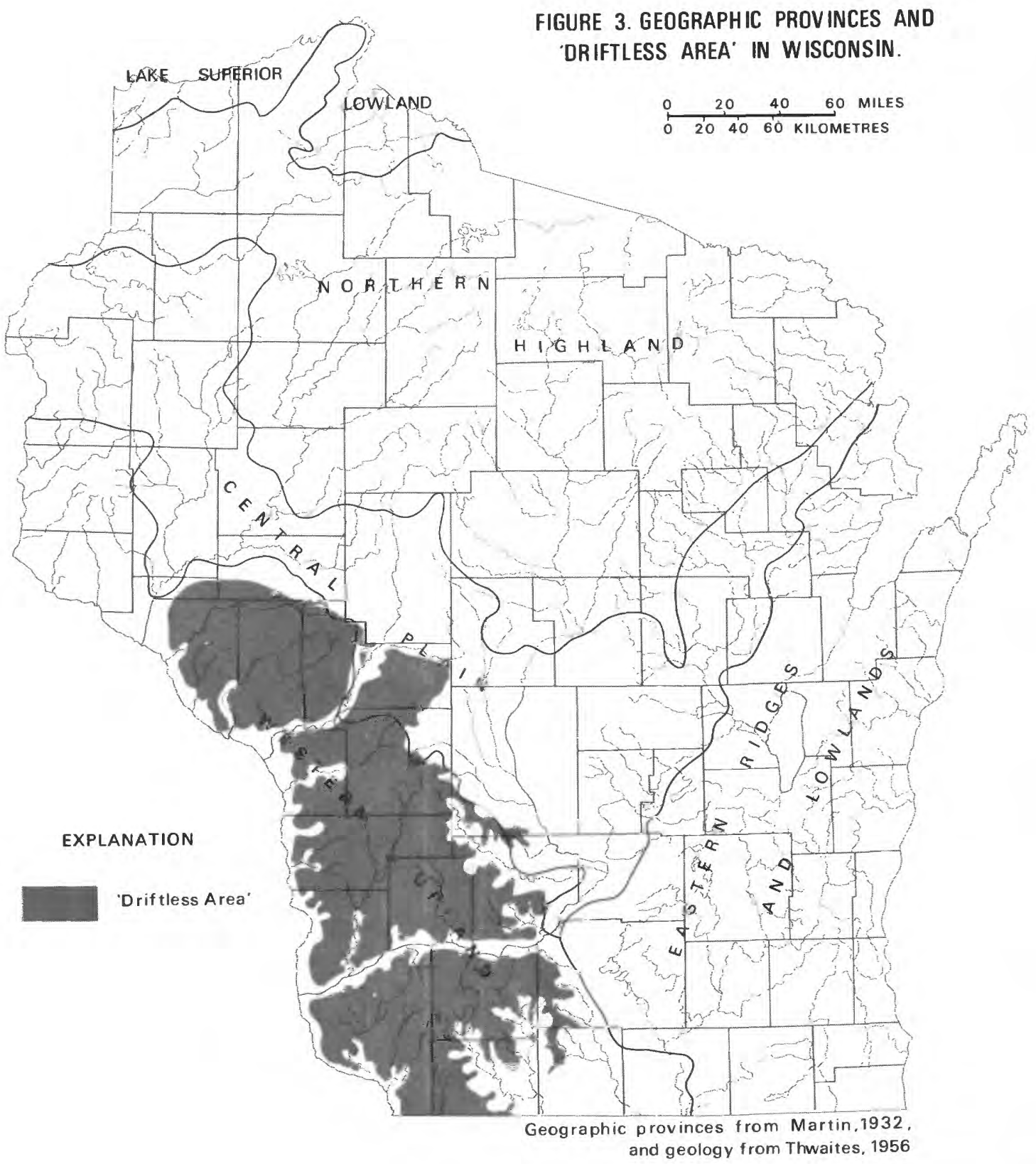


The Lake Superior Lowland province (fig. 3), which approximately outlines the red-clay soils in northwestern Wisconsin, has fairly high sediment yields. Data from stream basins only partly in the area give average annual suspended-sediment yields ranging from 140 to $220 \mathrm{tons} / \mathrm{mi}^{2}$ (49 to 77 tonnes $/ \mathrm{km}^{2}$ ). A yield of 480 tons $/ \mathrm{mi}^{2}$ (168 tonnes $/ \mathrm{km}^{2}$ ) was obtained for the one area that is completely in the red-clay area (Young and Skinner, 1974). Sufficient data are not available for the area to develop a meaningful median yield or to determine a really representative maximum yield. The high yields in this geologically young area are due in part to the easily erodible red clay that retards infiltration and promotes rapid surface runoff. Also, the rapid downcutting of stream channels leaving steep exposed red-clay streambanks that continually erode and fall into the streams is a major cause of the high yields.

\section{PREDICTING SEDIMENT YIELDS IN WISCONSIN STREAMS}

Because sediment-yield data are available for only a small percentage of Wisconsin streams and at only a few points on the streams, a method to predict sediment yields in the remaining streams of the State has been developed. The procedure is simple and requires only data that are readily available. It consists of equations that relate sediment yield to the geographic or physical factors that control sediment production and transport.

Geography is important in explaining difference in sediment yield between areas. Most of the physical factors that control sediment yields of streams are in some way related to geography. Physical factors such as geology, topography, soils, land use and cover, stream hydraulics, and climatic conditions all have a direct effect on sediment yields but are also all part of the geography of an area. The State has been divided into five geographic provinces as shown in figure 3 (Martin, 1932, p. 33). The "Driftless Area" of southwestern Wisconsin (Thwaites, 1956) provides an additional geographic division. (See fig. 3.) This is an area of the State that was not glaciated during Pleistocene time and that has very distinct surface features. These divisions make it possible to group streams according to geography, therefore lessening geographic differences between streams. Equations for predicting the sediment yields within each geographic division were developed by regression techniques that relate sediment yields to the physical factors that control sediment production and transport.

The regression equations were developed through a three-step procedure. The first step was selecting and grouping the stations to be used in the analyses. Only stations with drainage areas less than $1,000 \mathrm{mi}^{2}\left(2,590 \mathrm{~km}^{2}\right)$ and a sediment-transport curve well defined over the entire range of discharge were used. The 60 stations that met these requirements were then grouped according to their geographic province or geologic area. Next, the physical geographic factors that control sediment yield in each stream were defined, measured, and entered into 
the regression analysis as independent variables. The 14 physical factors used for this regression analysis were drainage area, average discharge, 2-year recurrence-interval flood, 25-year recurrence-interval flood, mainchannel slope, percentage lake and marsh area, main-channel length, percentage forest cover, soil index, precipitation-intensity index, flood runoff, vegetative factor, mean frost depth, and duration factor. (See glossary for definitions of the variables.) The dependent variable used in the regression analysis was the previously calculated suspendedsediment yield (table 1 ).

The final step was the computation of the regression equations by computer. The results of the computer analyses were examined to determine the most significant independent variables and best equation for each province or area. In the four regression equations developed for Wisconsin streams, the number of statistically significant independent variables ranged from 1 in the equation for the Northern Highland province to 9 for the Eastern Ridges and Lowlands province equation. Independent variables that were not statistically significant were not included in the equations shown in table 3 .

The regression equations, relating sediment yield to physical factors that control sediment yield, are in the form

$$
Q_{s}=a \cdot A^{b_{1}} \cdot Q_{a}{ }^{b_{2}} \cdot Q_{25}{ }^{b_{3}} \cdot s^{b_{4}} \ldots . \cdot
$$

where " $\mathrm{Q}_{\mathrm{S}}$ " is a statistical sediment yield; "A", "Q $\mathrm{Q}$ ", "Q25", and "S" are sediment-yield controlling factors as defined in the glossary; " $a$ " is the regression constant; and " $b_{1}$ ", " $b_{2}$ ", " $b_{3}$ ", and " $b_{4}$ " are coefficients obtained by regression. In the regressions presented in this report the computer calculated the regression equation, the standard error of estimate, and the significance of each geographic factor.

A principal measure of the accuracy of the regression analysis, hence the accuracy with which sediment yield can be estimated, is the statistical measure of error, "standard error of estimate". Even though standard error is only a measure of the accuracy of a regression equation, not actual sedimentation methods, it represents the accuracy of an estimated sediment yield using the regression equation at an ungaged site. It is the estimated limit above and below the average within which about 67 percent of future sediment-yield values are expected to fall. Conversely, there is only one chance in three that future values will differ from the average by more than one standard error.

The regression equations, 1 through 4, standard error of estimate, and statistical significance for four geographic provinces of the State are shown in table 3 . The computed versus measured sediment yields of streams in these four geographic provinces are given in table 4 . There is no regression equation available for the Lake Superior Lowland province because enough data were not available to run a regression. In this area 


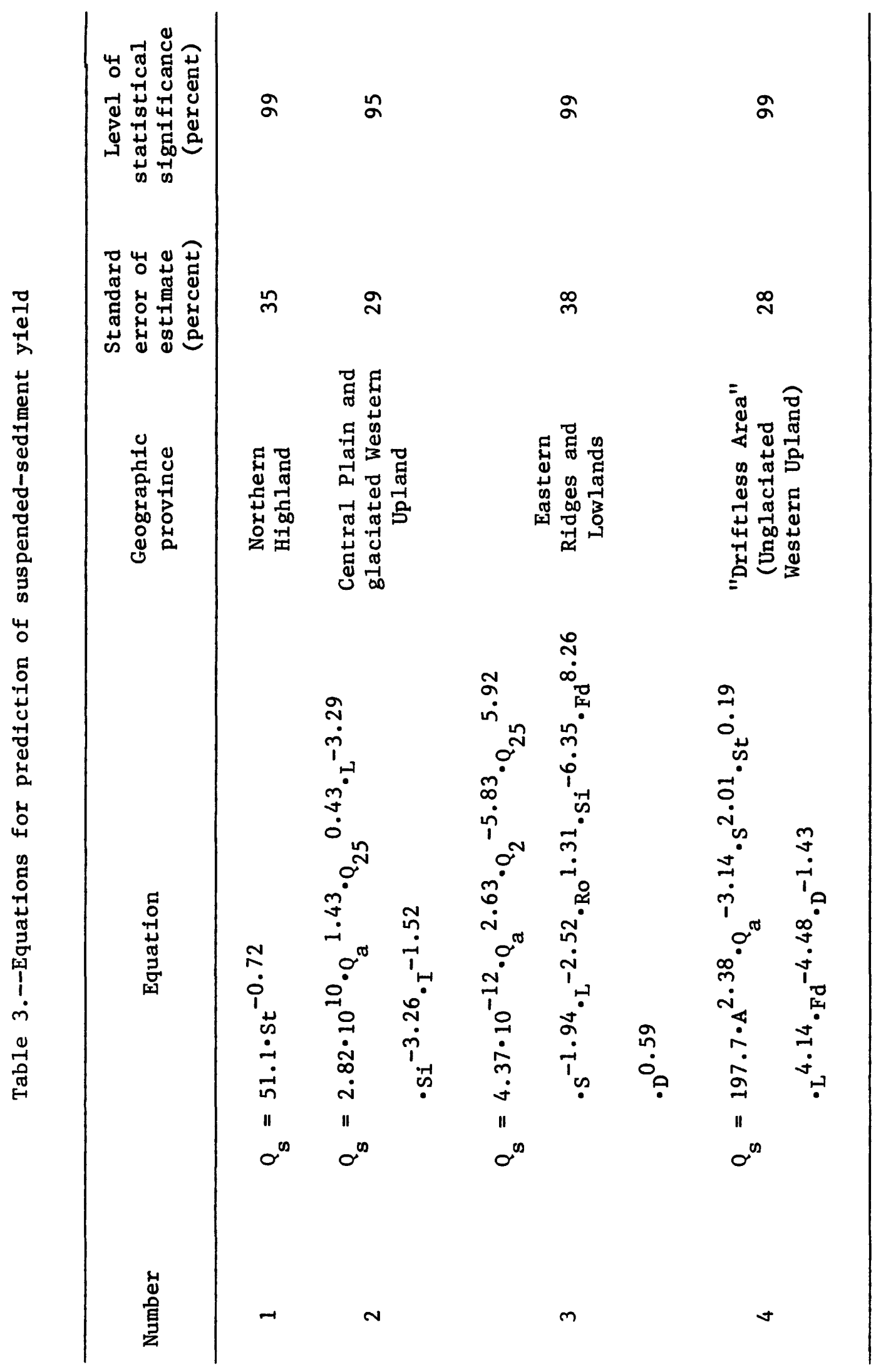


Table 4.--Observed versus computed average annual long-term suspended-sediment yields

\begin{tabular}{lcc}
\hline $\begin{array}{l}\text { Station } \\
\text { number }\end{array}$ & $\begin{array}{c}\text { Average annual suspended-sediment yields } \\
\left(\text { tons } / \mathrm{mi}^{2}\right)\end{array}$ \\
\cline { 2 - 3 } & Observed & Computed \\
\hline
\end{tabular}

Northern Highland Province

04025500

04026870

04061000

04063700

04066500

04071000

05359500

05362000

05393500

05394500

05397500

05399500

$\begin{array}{rr}9.6 & 7.2 \\ 10.0 & 10.0 \\ 10.0 & 9.9 \\ 3.3 & 4.8 \\ 6.9 & 6.6 \\ 3.1 & 6.7 \\ 3.8 & 4.1 \\ 8.9 & 6.5 \\ 8.1 & 6.6 \\ 8.5 & 5.3 \\ 7.8 & 8.9 \\ 31 & 32\end{array}$

Central Plain Province

04078500

04080000

04081000

05368000

05370000

05381000

05401050

05402000

05403500

05403630

05403700

\section{1}

30

31

29

18

50

34

15

20

9.4

16
9.3

36

21

30

17

47

34

17

22

12

12

Eastern Ridges and Lowlands Province

04071858

04073050

04085200

04085281

04086000

04086150

04086340

04086360

04086500
17

15

16

17

62

11

10

18

45
18

19

23

17

47

9.5

9.7

12

44 
Table 4.--Observed versus computed average annual 1ong-term suspended-sediment yields--Continued

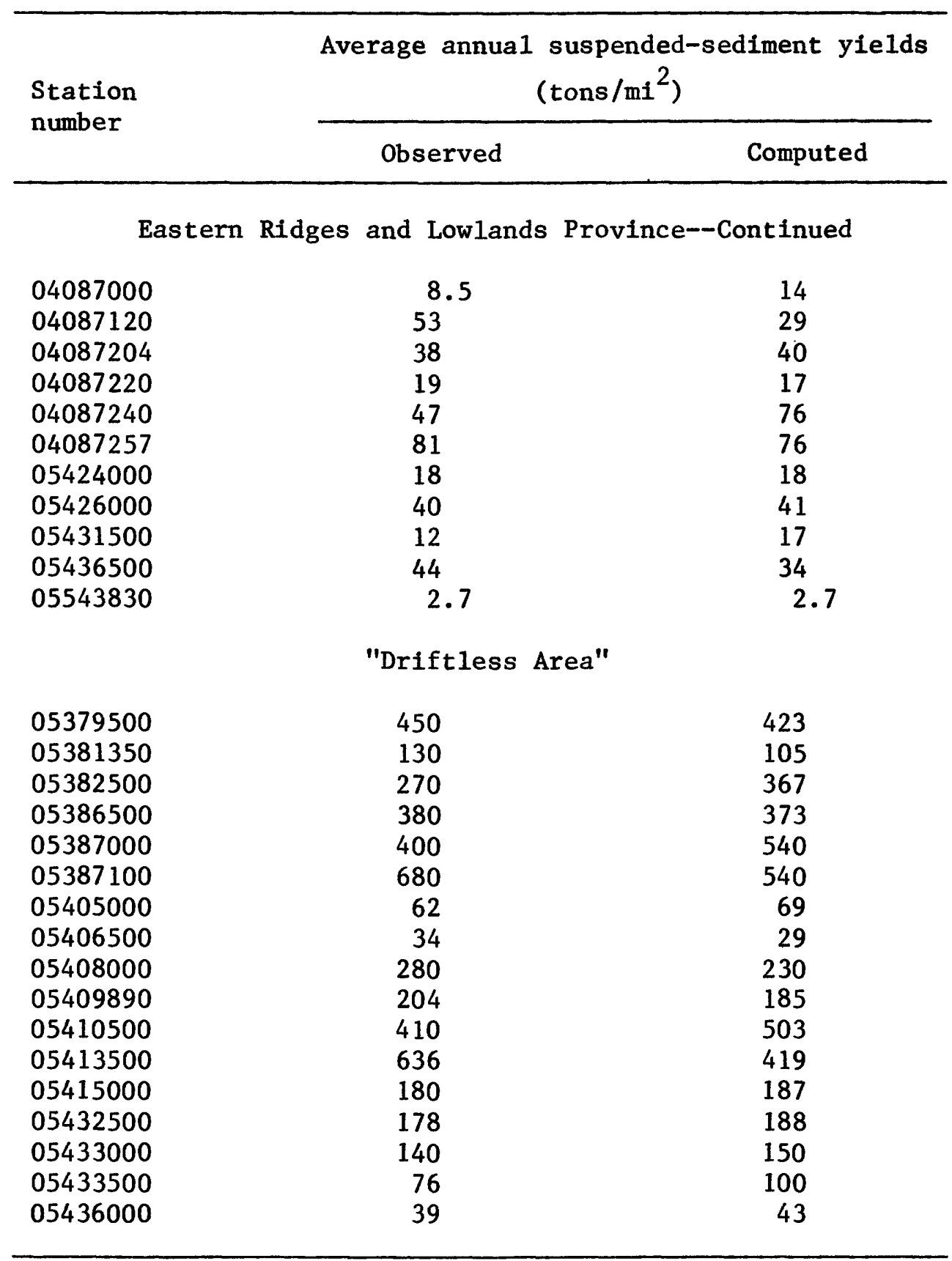


of the State other methods of sediment-yield estimation must be used. The "Driftless Area" was substituted for the Western Upland province. The "Driftless Area" and Western Upland province have similar boundaries except in the glaciated area of the Western Upland province. The effects of glaciation or lack of glaciation created two distinct geographic areas and are treated as such. To predict sediment yields in that part of the Western Upland province outside the "Driftless Area", the regression equation for the Central Plain province is applicable and gives very good results.

Different combinations of the 14 independent variables were found to be statistically significant for each of the four regression equations. The only significant independent variable in the equation for the Northern Highland province was percentage lake and marsh area. The remaining 13 variables used in the analysis were found to be statistically insignificant. The average discharge, 25-year recurrence-interval flood, main-channel length, soil index, and precipitation-intensity index are the only independent variables that were statistically significant in the equation for the Central Plain province. The remaining nine variables were disregarded. In the equation for the Eastern Ridges and Lowlands province the average discharge, 2- and 25-year recurrence-interval floods, mainchannel slope, main-channel'length, 10-year runoff, soil index, frost depth, and duration factor are the significant independent variables. Five remaining variables were found to be statistically insignificant for this province. The equation for the "Driftless Area" had seven statistically significant independent variables: drainage area, average discharge, main-channel slope, percentage lake and marsh area, main-channel length, frost depth, and duration factor. The remaining seven independent variables were insignificant and not included in the equation.

These regression equations make it possible to predict sediment yields for about 95 percent of Wisconsin streams. Use of the sediment-yield equations is illustrated below by a practical application to the Manitowoc River at Lake Michigan.

1. Determine from figure 3 the major geographic province of the Manitowoc River. In this example it falls completely in the Eastern Ridges and Lowlands province and therefore equation number 3 is applicable. Equation number 3 is as follows:

$$
\begin{aligned}
Q_{S}= & 4.37 \cdot 10^{-12} \cdot Q_{a}{ }^{2.63} \cdot Q_{2}{ }^{-5.83} \cdot Q_{25} 5.92 \cdot \mathrm{S}^{-1.94} \cdot \mathrm{L}^{-2.52} \\
& \cdot \mathrm{Ro}^{1.31} \cdot \mathrm{Si}^{-6.35} \cdot \mathrm{Fd}^{8.26} \cdot \mathrm{D}^{0.59}
\end{aligned}
$$

2. To calculate average discharge $\left(Q_{a}\right)$, in cubic feet per second, first determine the size of the contributing drainage area (A) from the best maps available. For the Manitowoc River it is about $530 \mathrm{mi} 2\left(1,373 \mathrm{~km}^{2}\right)$. 
Next, estimate the average runoff for the basin from figure 4. (See glossary.) In this example it is about $7.5 \mathrm{in}(19 \mathrm{~cm})$. Finally, multiply the drainage area by the average runoff and apply the necessary conversion factor (0.074) to get average discharge.

$$
Q_{a}=7.5 \cdot 530 \cdot 0.074=290 \mathrm{ft}^{3} / \mathrm{s}\left(8.21 \mathrm{~m}^{3} / \mathrm{s}\right)
$$

3. Compute the 2-, 10-, and 25-year recurrence-interval floods $\left(Q_{2}, Q_{10}, Q_{25}\right)$ from previous1y developed equations (Conger, 1971). (The 10-year recurrence-interval flood will be used in a later step.) For the Manitowoc River they are as follows:

$$
\begin{aligned}
& Q_{2}=3,900 \mathrm{ft}^{3} / \mathrm{s}\left(110 \mathrm{~m}^{3} / \mathrm{s}\right) \text { and } \\
& Q_{25}=8,100 \mathrm{ft}^{3} / \mathrm{s}\left(229 \mathrm{~m}^{3} / \mathrm{s}\right) .
\end{aligned}
$$

4. Determine the main-channel length (L) and slope (S) from topographic maps as follows: (a) Measure the river length, in miles, from the desired location to the basin divide. If the stream forks, follow the fork with the greater drainage area. This is channel length (L). (b) Determine altitudes at points that are 10 and 85 percent of the total river length. (c) Determine the difference between these altitudes and divide by the distance in miles between these points. The Manitowoc River is approximately $70 \mathrm{mi}(113 \mathrm{~km})$ long and has a slope of about $5 \mathrm{ft} / \mathrm{mi}(0.95 \mathrm{~m} / \mathrm{km})$.

5. The 10-year runoff (Ro) is calculated by dividing the Q10 by the drainage area from step 1.

$$
\begin{aligned}
& \mathrm{Q}_{10}=6,500 \mathrm{ft}^{3} / \mathrm{s}\left(184 \mathrm{~m}^{3} / \mathrm{s}\right) \text { and } \\
& A=530 \mathrm{mi}^{2}\left(1,373 \mathrm{~km}^{2}\right) .
\end{aligned}
$$

For the Manitowoc River it is approximately $12\left(\mathrm{ft}^{3} / \mathrm{s}\right) / \mathrm{mi}^{2}\left\{0.13\left(\mathrm{~m}^{3} / \mathrm{s}\right) / \mathrm{km}^{2}\right\}$.

6. The soil index figure (Si) of 2.90 in $(7.4 \mathrm{~cm})$ for the Manitowoc River was determined by the U.S. Department of Agriculture, Soil Conservation Service, upon request.

7. Frost depth (Fd) for the Manitowoc River is determined from figure 6 and is about 24 in $(610 \mathrm{~mm})$. (See glossary.)

8. The duration term (D) was determined through a correlation procedure with nearby U.S. Geological Survey continuous-record stations. The Manitowoc River is between the Kewaunee and Sheboygan Rivers, both of which have continuous-record gaging stations. By comparing the hydrologic and geographic characteristics of all three basins, an estimate of 23 was made for the duration term for the Manitowoc River. 
9. The final step in the example is substituting the calculated or estimated factors in equation number 3 and performing the necessary calculations. For the Manitowoc River the final equation is:

$$
\begin{aligned}
Q_{S}= & 4.37 \cdot 10^{-12} \cdot 290^{2.63} \cdot 3,900^{-5.83} \cdot 8,100^{5.92} \cdot 5^{-1.94} \\
& \cdot 70^{-2.52} \cdot 12^{1.31} \cdot 2.9^{-6.35} \cdot 24^{8.26} \cdot 23^{0.59} \\
Q_{S}= & 9.88 \cdot 10^{1}=99 .
\end{aligned}
$$

Solving the equation gives an estimated average annual suspended-sediment yield for the Manitowoc River of 99 tons $/ \mathrm{mi}^{2}$ (35 tonnes $/ \mathrm{km}^{2}$ ). This calculated yield appears to be somewhat high when compared to the regionalized sediment-yield map (fig. 2), but the map shows that Manitowoc River sediment yield could range from 30 to 100 tons $/ \mathrm{mi}^{2}$ ( 11 to 35 tonnes $/ \mathrm{km}^{2}$ ). Considering that equation number 3 has 38 percent standard error of estimate, the calculated yield and the yield map are in good agreement.

These equations are only a first step in developing models for prediction of sediment yields. As additional data become available and new statistical techniques are developed, more accurate and quicker procedures for prediction of sediment yields and even erosion and deposition rates should become available.

\section{GLOSSARY}

Dependent variable

1. Sediment yield $-\left(Q_{S}\right)$, expressed in tons per square mile per year, is the average amount of dry weight of suspended sediment that passes a stream section during 1 year divided by the area of the drainage basin.

Independent variables

1. Drainage area (A), in square miles, of a stream at a specified location is that area, measured in a horizontal plane, enclosed by a topographic divide from which direct surface runoff from precipitation normally drains by gravity into the stream above the specified point. Drainage areas have been determined for many basins in Wisconsin (Holmstrom, 1972).

2. Average discharge $\left(Q_{a}\right)$, in cubic feet per second, is the arithmetic average of daily mean discharges for a period of years. It çan be estimated from the drainage area and average runoff of the basin (fig. 4).

3. Two-year flood $\left(Q_{2}\right)$, in cubic feet per second, is the discharge of a flood that has a recurrence interval of once in 2 years. Regression techniques are available to determine $Q_{2}$ for any stream in the State (Conger, 1971). 


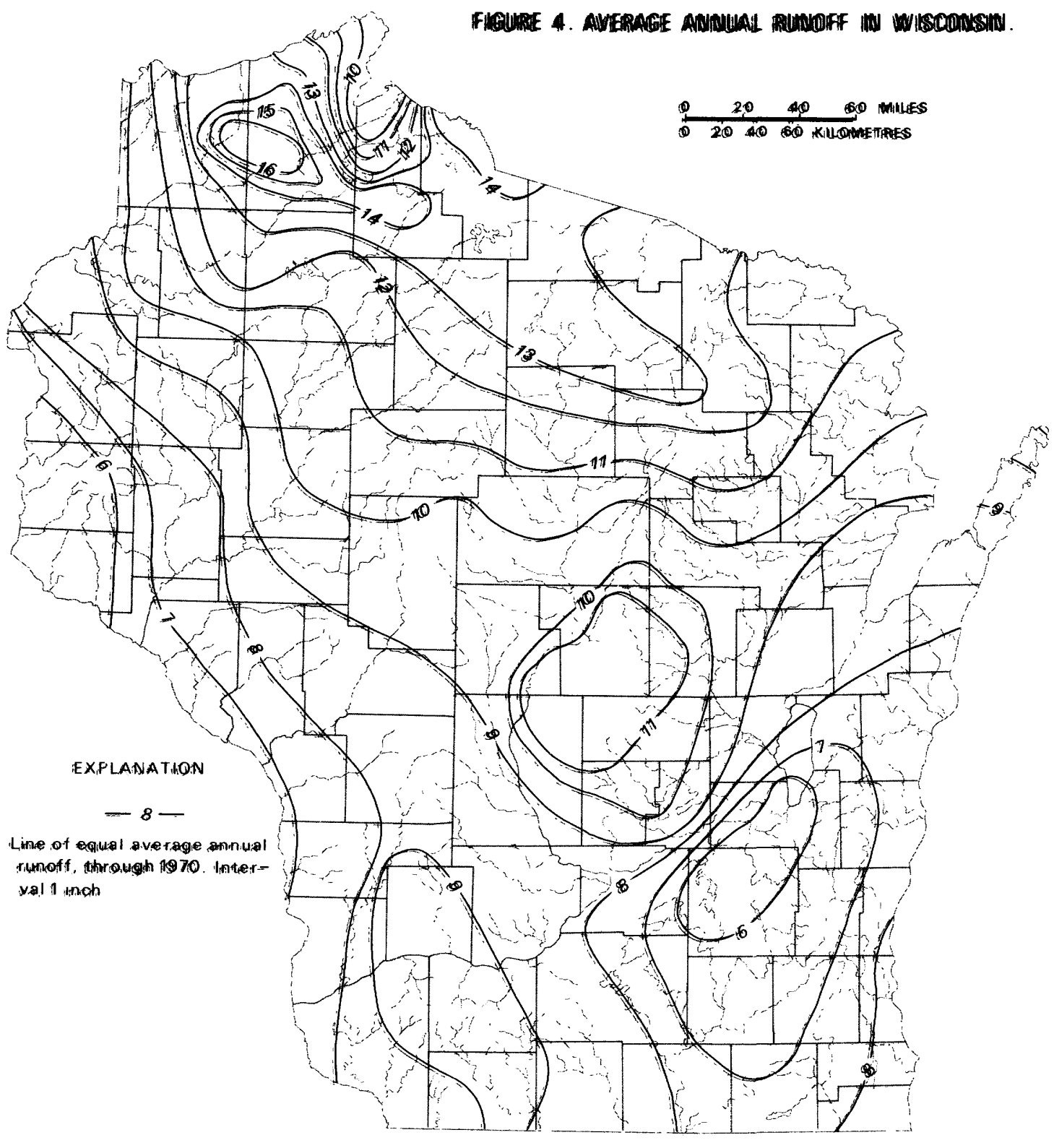


4. Twenty-five year flood $\left(Q_{25}\right)$, in cuble foet per secomil, is the discharge of a Hlood that has a recurremce imterval of once fin 25 years. Regresion techuiques are awallatie to determime Q25 for any stream im the Strate (Comger, 1971).

5. Matim-chamel siope (S)', Im feet per mulle, is the slope of the stream betwen points that are 10 and 85 percent of the distance aloms the chamel from the site where yields are to be detemumed to the basim divide. It cam be determimed from $\mathbb{t} . S$. Ceological survey quadramgle maps.

6. Lake amd marsin area (St), expressed as percemt of the fratimage

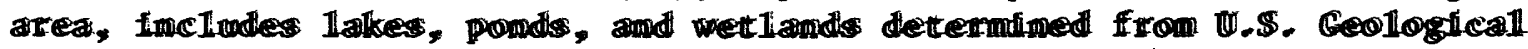
Swevey quadramgie maps and U.S. Department of Agriculture, Soll comservation Service, data. To avolid zero valiwes, a comstrat of 1 percent is adided to each value to obtain the vallue of $S_{t}$ to be wed im the regression. equation.

7. Hain-chammel Iength (IV), in miles, ts measwred from the site where yilid is to be determimed to the basini divide. It can be determimed from U.S. Gelogleal survey quadrangle maps.

8. Forest cover (F), expressed as a percemtage of the bastim dratimage area as shown on U.S. Cological swrwey quadrangle mas and data from the U.S. Department of Agriculture, Sol1 Comservatiom Service. To awoid zero, a constant of 1 percent is adied to each walue to obtatin the value of $F$ wed the regression equation.

9. Soll imdiex (SI), in imches, is am index of soil finfiltratiom capacity. It is avalials le from amid calculated the t.S. Department of Agriculture, Soll Conservation Service, from imfomation on soll type, vegetal cover, amd agricultural practices (R. W. Akeliey, witen commu, 1.974).

10. Precipitation-intemsity index (I) (2-year, 24-hour ralifali),

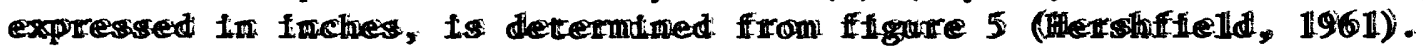
This maximum 24-hour ralnfali has a recurremce finterval of once tim 2 years.

11. Flood twoff (RO), in cublic feet per second per square mile, is the flood discharge that has a recurrence fmterval of once in 10 years, Q10. divided by the dratmage area of the basim. Dratimase arrea data are from varlable 1 above and the flood data cam be detemined as im vartabies 2, 3, and 4 above.

12. Vegetative factor (V), in inches per degree $F$, is the meam ammal preciptitation divided by mean anmual temperature and ma be determined from maps avaliale from the Wiscomsim statistical Reportho Service $(1967)$.

13. Mean frost depth on February 28 (Fd), 1961-68 average in inches, is determined from figure 6 (Wisconsin statistical Reporting service, 1970, p. 13). 


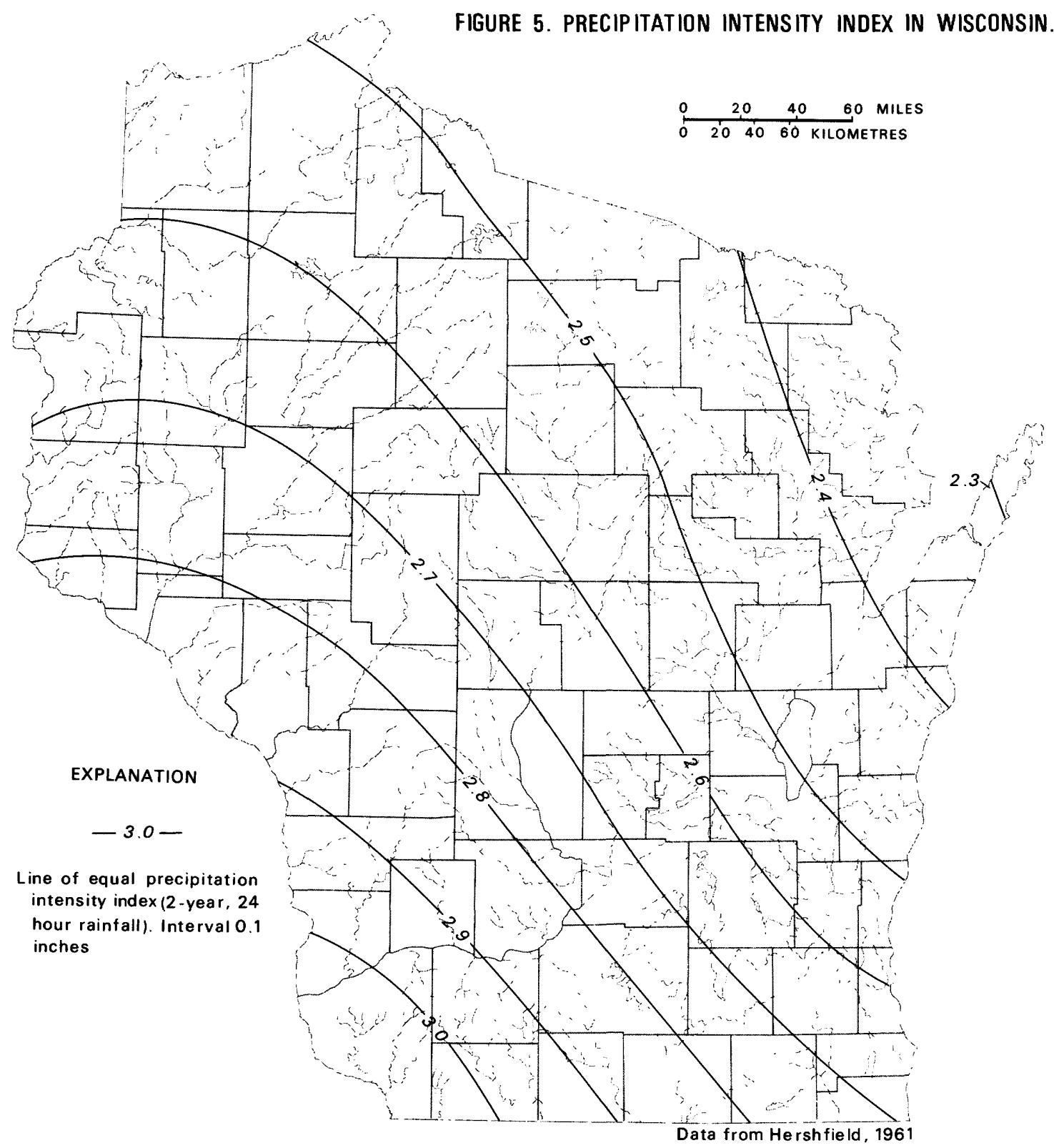



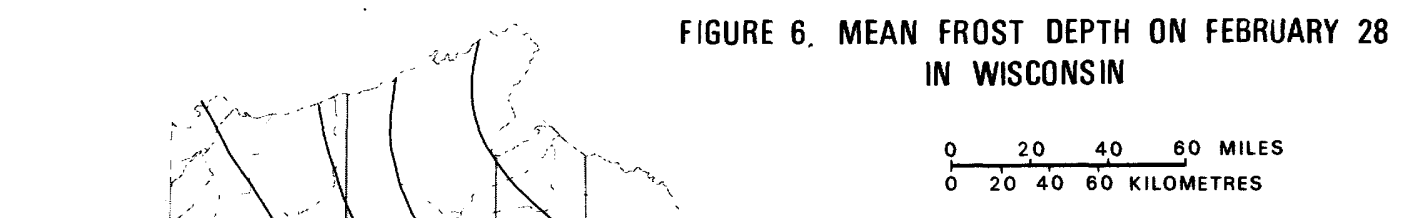

$-18-$

Line of equal mean frost

dep th on February 28, 1961 -

1968. Interval irregular, in

inches

$\begin{array}{llllll}0 & 20 & 40 & 60 & \text { MILES } \\ 0 & 20 & 40 & 60 & \text { KILOMETRES }\end{array}$
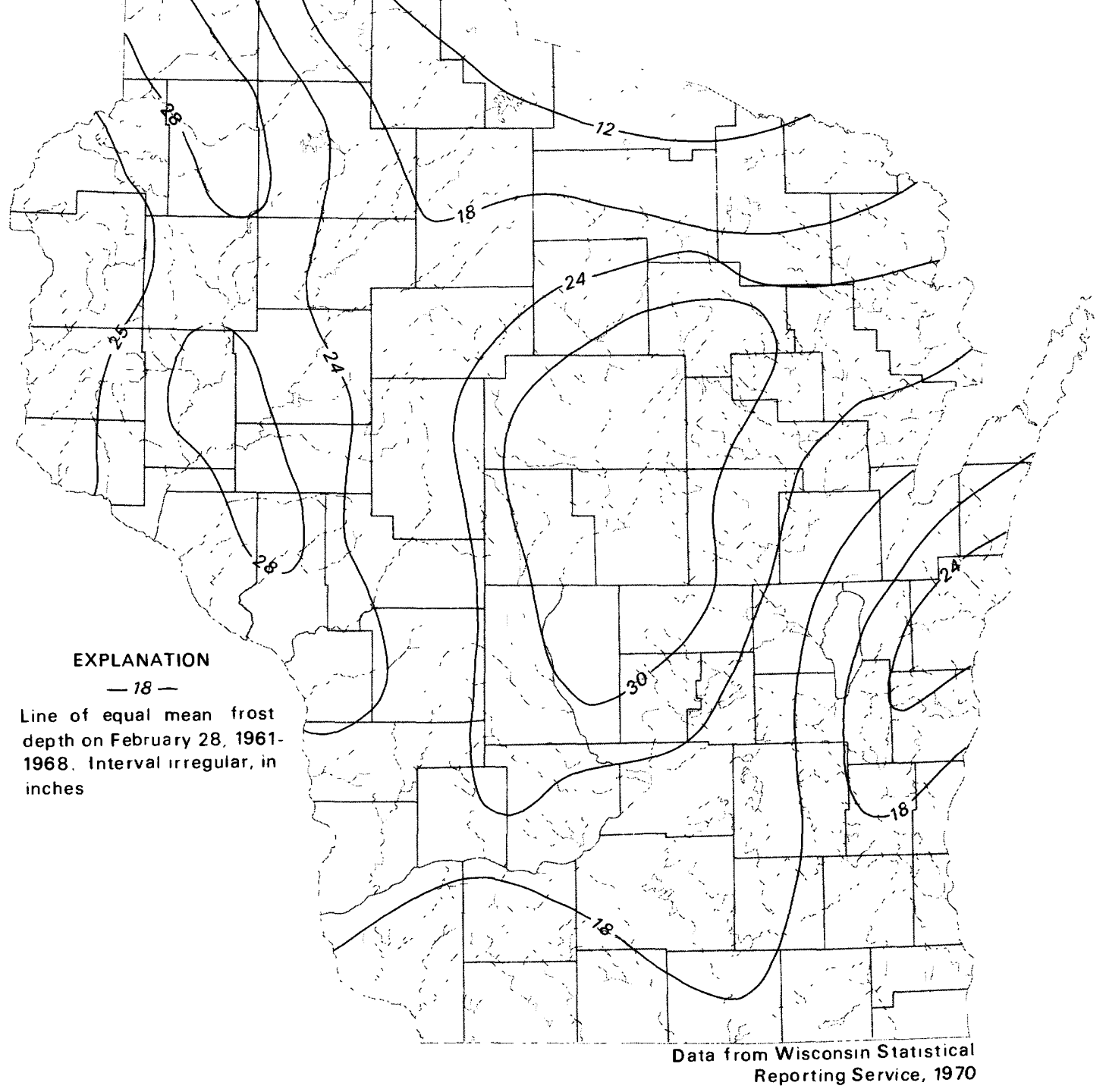
14. Duration factor (D) is the stream discharge that can be expected to occur at least 10 percent of the time divided by the discharge that can be expected to occur 90 percent of the time. Duration data are available from stream-gaging records.

\section{SELECTED REFERENCES}

Collier, C. R., 1963, Sediment characteristics of small streams in southern Wisconsin, 1954-59: U.S. Geol. Survey Water-Supply Paper 1669-B, $34 \mathrm{p}$.

Conger, D. C., 1971, Estimating magnitude and frequency of floods in Wisconsin: Madison, U.S. Geo1. Survey open-file rept., 200 p.

Guy, H. P., 1969, Laboratory theory and methods for sediment analysis: U.S. Geol. Survey Techniques of Water Resources Inv., Book 5, Chap. C1, 58 p.

Hershfield, D. M., 1961, Rainfall frequency atlas of the United States: U.S. Weather Bureau Tech. Paper 40, 115 p.

Hinda11, S. M., 1972, Sediment yields of Wisconsin streams: U.S. Geo1. Survey open-file rept., 1 p.

Hinda11, S. M., and Flint, R. F., 1970, Sediment yields of Wisconsin streams: U.S. Geo1. Survey Hydro1. Inv. Atlas HA-376.

Holmstrom, B. K., 1972, Drainage-area data for Wisconsin streams: Madison, U.S. Geol. Survey open-file rept., 76 p.

Martin, Lawrence, 1932, The physical geography of Wisconsin: Wisconsin Geo1. and Nat. History Survey Bull. 36, 608 p.

Rainwater, F. H., 1962, Stream composition of the conterminous United States: U.S. Geo1. Survey Hydrol. Inv. Atlas HA-61.

Thwaites, F. T., 1956, Glacial features of Wisconsin: Wisconsin Geo1. and Nat. History Survey open-file map.

U.S. Geological Survey, 1966, Water resources data for Wisconsin, 1965: U.S. Geol. Survey ann. rept., 212 p.

1967, Water resources data for Wisconsin, 1966: U.S. Geol. Survey ann. rept., $215 \mathrm{p}$.

1968, Water resources data for Wisconsin, 1967: U.S. Geol. Survey ann. rept., 215 p. 
1970, Water resqurces data for Wisconsin, 1968: U.S. Geol. Survey ann. rept., $218 \mathrm{p}$.

1971, Water resources data for Wisconsin, 1969: U.S. Geo1. Survey ann. rept., $247 \mathrm{p}$.

1972, Water resources data for Wisconsin, 1970: U.S. Geo1. Survey ann. rept., $254 \mathrm{p}$.

1973, Water resources data for Wisconsin, 1971: U.S. Geo1. Survey ann. rept., $221 \mathrm{p}$.

1974, Water resources data for Wisconsin, 1972: U.S. Geo1. Survey ann. rept., 258 p.

1974, Water resources data for Wisconsin, 1973: U.S. Geo1. Survey ann. rept., $258 \mathrm{p}$.

Wisconsin Statistical Reporting Service, 1967, Wisconsin weather: Madison, Wisconsin Statistical Reporting Service, 31 p.

1970, Snow and frost in Wisconsin: Madison, Wisconsin Statistical Reporting Service, 28 p.

Young, H. L., and Skinner, E. L., 1974, Water resources of Wisconsin-Lake Superior basin: U.S. Geol. Survey Hydrol. Inv. Atlas HA-524. 

